\title{
Effect of Seeding Rate On Growth And Yield Of Okra (Abelmoschus Esculantus) In Zuru Northern Guinea Savanna Of Nigeria
}

\author{
Yohanna J, A. ${ }^{1}$ and Muhammad A, M. ${ }^{2}$ \\ Department Of General Studies, Federal University Wukari, Taraba State, Nigeria. \\ yjohnalhassan@gmail.com \\ 2. Department of Entrepreneurship Education, College of Agriculture Zuru, Kebbi State \\ Muhammadalhaji99@gmail.com
}

\begin{abstract}
Field experiment was carried out during 2010 rainy season to find the effect of seeding rate on the growth and yield of okra (Abelmuschus esculentus) in Zuru Northern Guinea Savannah. Zuru is located in Zuru Local government area of Kebbi State (Latitude $11^{\circ} 25^{1}$ to $11^{\circ} 55^{1}$ North and Longitude $4^{\circ} 5^{1}$ to $5^{\circ} 25^{1}$ East of the equator). The experiment consisted of three treatments that is planting okra at one plant per stand $\left(S_{1}\right)$, two plants per stand $\left(S_{2}\right)$ and three plants per stand $\left(S_{3}\right)$. The experiment was laid out in randomized complete block design (RCBD) and the treatments replicated three time. The result of the experiment has shown that plant height and number of leaves/plant at 3,6 and 9 weeks after planting (

WAP) were significantly influenced by seeding rate $(\mathrm{P}<0.05)$. At 3,6 and 9 WAP tallest plants were obtained from okra plants planted at three plants/stand $(27.83,54.0$ and $77.0 \mathrm{~cm})$ respectively followed by okra planted at two plant/stand (24.77, 50.67 and 74.33 leave/plant respectively ). However, more number of leaves/plant were obtained from okra plant at one plant/stand $(9.67,24.67$ and 48.0 leaves/plant respectively) followed by okra planted at two plants/stand $(8.33,18.33$ and 36.33 leaves/plant respectively). Seeding rate had significant influence on time of 50 percent flowering with one plant/stand first attaining 50 percent flowering stage just within 36.33 days followed by okra planted at two plants/stand (38 days). The mean fresh fruit yield of okra was also significantly influenced by seeding rate with the highest yield of fresh fruits obtained from three plants/stand (83.34/ha) followed by okra planted at two plants/stand (55.56/ha). However, the result of the findings recommends that, okra should be planted at two plants/stand for medium sized and marketable okra fresh fruits since at three plants/stand leads to the production of undersized fresh fruits which do not often attract customers. At one plant/stand, there seemed to be early fruiting and bigger sized fresh fruits but low total yield due to underutilization of land resource/space. Planting at one plant/stand should therefore be avoided
\end{abstract}

Keyword: Seeding Rate, Okra, Growth, Yield,

\section{Introduction}

Okra (Albemuschus esculentus) is one of the most popular vegetable crops grown in Nigeria. It is an important item in cooking and can be used either at fresh stage or dried. Fresh pod is edible and rich in vitamin $\mathrm{A}, \mathrm{B}$ and $\mathrm{C}$ and it can be dried and stored. The crop performs well in the study area and thus apart from nutritional value it also provides a good source of income to the producers. A lot of researches have been carried out to improve on the performance of the crop but less attention is paid on the effect of plant density on the growth and performance of okra especially in the study area. This research work was designed to adopt different plant population with a view to finding the most suitable population per stand for maximum growth and yield of okra. 
The study seek to determine the appropriate number of plants/stand needed for better growth and yield of okra, to determine the amount of okra seeds required per stand for better growth and yield of okra.

Most farmers did not know the exact number of plant/stand for maximum growth and yield of okra. This research was designed to answer the stated question. The research is expected to acquaint farmers and related research workers on the appropriate amount of okra plant/stand needed for normal growth and hence production of okra plant.

The influence made at this research will go a long way in assisting farmers to improve on the production of okra through adoption of suitable plants/stand under field.

The investigation into the effect of seeding rate on the growth and yield of okra was focused on production of okra at the college of Agriculture, Zuru, Training and research Farm, in Zuru local government area of kebbi state.

\section{Materials and Methods}

The research was conducted at the College of Agriculture, Zuru Orchard, situated in Zuru local government area Kebbi State. The research was carried out during the 2010/2011 rainy season. Zuru is located in the Northern Guinea Savannah zone of Nigeria. It lies across latitude $11^{\circ} 35^{1}$ to $11^{\circ} 55^{1}$ South and Longitude $4^{\circ}$ $45^{1}$ to $5^{\circ} 25^{1}$ East, covering an area of approximately 19,999 square miles.

They are found at the extreme southern part of Kebbi State (Anonymous, 1991). Zuru has a favorable climatic condition for growing most crops when compared with other areas in the state.

The soil is moderately deep and well drained, with sandy loamy soil characteristics. The average rainfall is about $182 \mathrm{~mm} /$ annum with mean temperature of about $37^{\circ} \mathrm{C}$. The dry season is between April to May/June. During this period relative humidity is over $80 \%$ in the afternoon. The area also experienced a cold (Hammatan) season from November to January/February (Samuel, 1998).

The majority of the people in Zuru local government area are predominantly peasant farmers, who engaged in cultivation of various types of food crops such as maize, millet, sorghum, rice, cowpea, groundnut and soya beans. Tree crops cultivated include guava, cashew, mango and citrus, vegetables produced include spinach, tomatoes, pepper, eggplant, okra, etc. (Samuel, 1998).

The experiment consisted of three treatments (3) which include one plant/stand $\left(\mathrm{S}_{1}\right)$ two plants/stand $\left(\mathrm{S}_{2}\right)$ and three plants/stand $\left(S_{3}\right)$. The treatments were replicated three (3) times in a randomized complete block design (RCBD)

\section{Results}

The result obtained from the experiment were interpreted and discussed in table:

Table 1: mean plant height $(\mathrm{cm})$ of okra at 3, 6 and 9 W.A.P

\begin{tabular}{llll}
\hline Seeding rates & \multicolumn{2}{l}{ Plant height $(\mathbf{c m})$} \\
& 3W.A.P & 6 W.A.P & 9 W.A.P \\
\hline One plant/stand & $22.83^{\mathrm{C}}$ & $46.00^{\mathrm{C}}$ & $69.67^{\mathrm{C}}$ \\
Two plant/stand & $24.77^{\mathrm{b}}$ & $50.67^{\mathrm{b}}$ & $74.33^{\mathrm{b}}$ \\
Three plant/stand & $27.83^{\mathrm{a}}$ & $54.00^{\mathrm{a}}$ & $77.00^{\mathrm{a}}$ \\
LSD $(0.05)$ & 0.577 & 4.16 & 9.96 \\
\hline
\end{tabular}

(Source: Field work, 2010) 
Table 2. Mean number of leaves/plant of okra at 3, 6 and 9 W.A.P as influenced by seeding rate

\begin{tabular}{llcc}
\hline Seeding rates & \multicolumn{3}{c}{ Number of Leaves/plant } \\
& 3W.A.P & 6 W.A.P & 9 W.A.P \\
\hline One plant/stand & $9.67^{\mathrm{a}}$ & $24.67^{\mathrm{a}}$ & $48.00^{\mathrm{a}}$ \\
Two plant/stand & $8.33^{\mathrm{b}}$ & $18.33^{\mathrm{b}}$ & $36.33^{\mathrm{b}}$ \\
Three plant/stand & $6.00^{\mathrm{c}}$ & $14.00^{\mathrm{c}}$ & $36.33^{\mathrm{c}}$ \\
LSD (0.05) & 4.64 & 8.3 & \\
Significance & $\mathrm{S}$ & $\mathrm{S}$ & $\mathrm{S}$ \\
\hline
\end{tabular}

(Source: Field work, 2010)

Table 3.Mean time (days) of $50 \%$ flowering as influenced by seeding rate

\begin{tabular}{ll}
\hline Seeding rate & Mean time (days) of 30\% flowering. \\
\hline One plant/stand & $36.33^{\mathrm{c}}$ \\
Two plant/stand & $38.00^{\mathrm{DC}}$ \\
Three plant/stand & $47.60^{\mathrm{a}}$ \\
LSD $(0.05)$ & 5.49 \\
\hline
\end{tabular}

Source: Field work, 2010

Table 4. Mean fresh yield (t/ha) of okra as influenced by seeding rate

\begin{tabular}{ll}
\hline Seeding rate & Yield (t/ha) \\
\hline One plant/stand & $27.78^{\mathrm{c}}$ \\
Two plant/stand & $55.56^{\mathrm{b}}$ \\
Three plant/stand & $83.34^{\mathrm{a}}$ \\
LSD $(0.05)$ & 3.74 \\
& \\
Significance & $\mathrm{S}$ \\
\hline
\end{tabular}

Source: Field work, 2010

\section{Discussion}

\section{Mean plant height $(\mathrm{cm})$ of okra at 3, 6, 9 w.a.p}

The result on plant height of okra plant as effected by seeding rate at $3 \mathrm{WAP}$ is presented in table 1. the result has shown that plant height was significantly $(\mathrm{P}<0.05)$ influenced by seeding rate at 3, 6 and 9 W.A.P. treatment at one plant per stand produce taller at the three stage of growth $27.83 \mathrm{~cm}, 54 \mathrm{~cm}$ and $77 \mathrm{~cm}$ respectively, followed by two plants/stand $(24.77 \mathrm{~cm}, 50.67 \mathrm{~cm}$ and $74.33 \mathrm{~cm})$ shortest plants were obtained from three plant/stand treatment. This result is in agreement with the report of Adejonwu (1989).

\section{Means number of leaves /plant at 3,6 and 9 W.A.P}

Okra plants grown at one plant/stand produced more number of leaves at 3, 6 and 9 WAP $(9.67,24.67$ and 48.00 leaves) respectively followed by okra plant grown at two plants/stand. Which produced (8.33, 18.33 and 36.33 leaves/plant respectively). This result is in agreement with the report of Macdonald et al., (1984).

\section{Mean time (days) of $50 \%$ flowering}

The time (days) of 50\% flowering was significantly affected by seeding rate. The result has shown that okra left at one plant/stand flowering early (3, 6 DAP) followed by okra left at two plants/stand (38 DAP). The two treatments were not statistically significant at $5 \%$ level of significance. This contradicts with the report of Kochar (1986). 
In table 3. Means not followed by similar letters are significantly different at 50\% level of significance

\section{Mean fresh yield (t/ha) of okra}

Result on the fresh fruit yield of okra ( $t / h a)$ as influenced by seeding rate is presented in table 4.Above. The result shows that, fresh fruit yield (t/ha) of okra at three plants/stand produced highest fresh fruit yield (83.78t/ha) one plant/stand produced the lowest fresh fruit (27.78t/ha). The reason for the higher yield of fresh fruit in okra at three plants/stand might be due to more number of fruits per stand as compared to the other two treatments. However, the many number of fruits of low market value. Fruits of good market value. Fruits of good marketability were those obtained from two plants/stand. One plant/stand treatment resulted in bigger sized fruits but the few fruits produced per plant that constituted the stand has resulted in lower yield of fresh fruits. This result was confirmed with the findings of Klassen (2005)

\section{Conclusion}

The research work was conducted at College of Agriculture's Student research and Training Farm Zuru to find the effect of seeding rate on the growth and yield of okra (Abelmschus esculentus) during 2010 rainy season.

Zuru is located in the Northern Guinea Savannah in Kebbi State (Latitude $11^{\circ} 25^{1}$ to $11^{\circ} 55^{1}$ North and Longitude $4^{\mathrm{o}} 5^{1}$ to $5^{\mathrm{o}} 25^{1}$ East of equator). The experiment consisted of three treatments that is planting of okra at one plant per stand $\left(S_{1}\right)$ two plants per stand $\left(S_{2}\right)$ and three plants per stand $\left(S_{3}\right)$. The experiment was laid out in randomized complete Block Design (RCBD) and the treatments replicated has shown that plant height and number of leaves/plant at 3, 6 and 9 weeks after planting (WAP) were significantly influenced by seeding rate $(\mathrm{P}<0.05)$. at 3, 6 and 9 WAP tallest plant were obtained from okra plant planted at three plants per stand $27.87,54.0$ and $77.0 \mathrm{~cm}$ respectively. More number of leaved was obtained from okra planted at one plant per stand 9.67, 24.67 and 48.0 leave/plant at 3, 6 and 9 WAP respectively. Seeding rate had also significant influence on time of 50 percent flowering with one plant per stand first attaining 50 percent flowering stage just within 33-36 days followed by okra plants at two plants per stand (38 days) the mean fresh fruit yield of okra was also significantly influenced by seeding rate with the highest yield of fresh fruits obtained by three plants per stand $(83.34 \mathrm{t} / \mathrm{ha})$ followed by okra planted at two plants per stand (55.56 t/ha).

\section{Recommendation}

Based on this research work, we recommended the following points to be put into consideration in order to have an optimum growth and yield, thus:-

1. Okra should be planted at three plants per stand for medium sized and marketable okra fruits which do not often attract the consumers.

2. Planting at one plant per stand should be avoided for economic yield of okra.

\section{References}

[1] Adejonwo, K. O; et al (1989). Effect of variety nitrogen and period of weed interference on growth and yield of okra (Ambelmoschus esculentus) 2. Moenoh Nigeria Journal of weed science 2:21-27

[2] Anonymous, (1994), Weed control recommendations for Nigeria, series, No. 3, National committee on Weed control, the Dept. of Agriculture, Fed. Ministry of Agriculture Ibadan, Africa-Link Book Ltd. Pp 55-57.

[3] Delannoy, G. (2001). Vegetables in Raemokers, R.H (Ed) crop production in tropical Africa, DGLD Belgium, Pp 453-458.

[4] Kochar, S.L (1986). Tropical crops, a textbook of Economic Botany, Macmillan publishers Ltd., Besington pp 467-470. 
[5] Komolafe, M.F (1980) Agricultural science for West African School and Colleges, Oxford University press, London. Pp 229-231.

[6] Klassen, W. (2005) University of Florida, Miami-Dade Country extension, Hanestead, F.L U.S.A 4: $120-123$.

[7] Macdonald, et al., (1984). Fruit and vegetables publishers Evans mother (Nigeria publishers) Ltd. Ibadan Pp 135.

[8] Martins, F.N (1982) Okra potentials zone and Tropical, Pp 192-195

[9] Melifonwu, A.A (1999). Effects of varying period of weed interference on the yield of okra ( $A$. esculentus)in the humid tropical forest of South-Eastern Nigeria. Agricultural Journal, the Agricultural Society of Nigeria. Pp 115-121.

[10] Philips, T.A (1977). Agricultural none book, Longman, New Edition, Pp 26-81.

[11] Rag have, M. (1996). Influence of date of sowing and planting spacing on growth and yield of okra. Recent Hort, 3:99-101.

[12] Samuel, D.C (1998). Okra production, Horticulture information leaflets. North Carolina State University, $2^{\text {nd }}$ edition, Pp. 150-155.

[13] Singh, I.P (1995): Effect of various dosages of nitrogen on seed yield and quality of Okra (Abelmoschus esculentus) 16:227-229. 